\title{
Evaluation of the Competitiveness of Statistical Regions in Latvia Using Official Statistical Information
}

\author{
Ilze Judrupa' ${ }^{1}$, Maija Senfelde ${ }^{2}$, Vytautas Juscius ${ }^{3}$
}

${ }^{1,2}$ Riga Technical University

Kalnciema st. 6, LV-1048, Riga, Latvia

E-mail.ilze.judrupa@rtu.lv; maija.senfelde@rtu.lv

${ }^{3}$ Klaipeda University

Herkus Mantas st. 84, LT-92294, Klaipeda, Lithuania

E-mail.ek.shmf@ku.lt

cross $^{\text {ref }}$ http://dx.doi.org/10.5755/j01.ee.32.2.27979

There is a lack of methodologically grounded and generally accepted regional competitiveness' evaluation method in Latvia. Common feature of the research about nature of competitiveness is that competitiveness of a region depends on how high and sustainable the level of prosperity in the region is. The analysis of scientific literature showed, that most often synthetic indexes are used to evaluate competitiveness of a region. Methodology to evaluate regional competitiveness was developed and approbated in case of Latvia. To identify the most appropriate method for competitiveness index calculation, Regional Competitiveness Index (RCI) according to two different methods was calculated in the research. The results obtained were similar, but each of index calculation methods has its own advantages and disadvantages and the choice of the appropriate method will depend on the researcher's goals and objectives. Use of relative weights in index calculations affects the obtained results, therefore, necessity of relative weights must be economically justified. It was proven that regional competitiveness cannot be characterized by such simple indicators as GDP or GDP per capita. RCI shows the level of competitiveness of Latvia's statistical regions, it is possible to compare regions in time and among each other. It allows to form regional development policy and strategy more reasonably.

Keywords: Concept of Competitiveness; Regional Competitiveness, Regional Competitiveness Index, Relative Weights, Ranking.

\section{Introduction}

The need for a complex assessment of regional development is highlighted with Latvia's involvement in international integration processes. The issue of evaluating and increasing the competitiveness of Latvia and its regions in the international context is becoming increasingly important. In the context of the equal development of territories, it is important to create equal opportunities for jobs and infrastructure, access to health, education and cultural institutions for all residents of Latvia. It is necessary to develop a scientifically based methodology for regional competitiveness evaluation to analyze competitiveness of regions of Latvia and continue work on regional development policy more effectively. Till nowadays there is a lack of methodologically grounded and generally accepted regional competitiveness' evaluation method in Latvia that planners of regional policy could use to get information about current state of regions and possible trends in future.

The main aim of the research is to offer methodology for the evaluation of regional competitiveness and evaluate competitiveness of the statistical regions in Latvia.

The main objectives to reach the aim are the following:

- to do literature review about the concept of competitiveness;

- to develop model for the evaluation of regional competitiveness using only official statistical data;
- to approbate the model in the case of Latvia;

- to assess competitiveness of statistical regions of Latvia by Regional Competitiveness Index (RCI) calculated by two different methods, comparing their advantages and disadvantages;

- to identify whether the relative weights have an effect on the values of RCI and evaluation of competitiveness level of regions;

- to assess whether simple indicators such as GDP, GDP per capita or GDP per employee could be used to evaluate competitiveness of regions.

Novelty of the research is identification of the main sources and results of competitiveness; development of methodology to evaluate regional competitiveness using official statistical information; comparison of the RCI results for statistical regions of Latvia according to two different methods; assessment of the importance of relative weights in the RCI.

Research methods applied: analysis and synthesis, induction and deduction, literature review (primary and secondary literature sources), expert method, statistical analysis of quantitative data, cross-sectional and longitudinal study, index calculation method, correlation analysis, and ranking.

Limitations of the research: research period 2000 2019; to calculate the index only secondary data from official statistical sources were analyzed; due to time and scope of the study only internal factors of regional 
competitiveness were analyzed. The assumption is that external factors for all regions of Latvia are the same.

To improve the quality of the Regional Competitiveness Index it is possible to include also qualitative data from surveys that will better characterize some of the competitiveness aspects to calculate this index. But collection of such data will need extra resources and time.

\section{Literature Review}

Research on regional competitiveness and its concepts has been developed by many authors. They mostly differ because of the various factors that are seen as sources of competitiveness. Also the outcome or result of competitiveness could be different, but there are less differences between them than among sources of competitiveness. The main goal of higher competitiveness could be the achievement of the following goals - high level of regional development or rapid economic growth, as well as high level of welfare or quality of life, or sustainability.

Historical perspective of competitiveness was already analyzed by Garelli (2006). He mentioned the following authors - A. Smith, D. Ricardo, K. Marx, F. Engels, J. Schumpeter, P. Drucker, R. Solow, M. Porter and others in his work "Competitiveness of Nations: The Fundamentals". Smith (1776) and Ricardo (1817) as cited in Garelli (2006) described competitiveness of a country as its ability to produce and export goods. But they had different views on this - D. Ricardo developed A. Smith's idea of absolute advantage and created the concept of comparative advantage. Marx (1867) emphasized the influence of the socio-political environment on economic development, thus showing that communist ideas form the political context for economic development. Weber (1905) as cited by Garelli
(2006) found a connection between value, religious belief, and the economic development of nations.

Entrepreneurship, innovations, technological development have been defined as main factors of competitiveness starting from Schumpeter's "Creative destruction" concept, which describes the process that sees new innovations replacing existing ones and is closely linked with his view of the importance of economic dynamism (Shumpeter, 1942, as cited in Adler, 2019), to nowadays. Export capacity is also one of the competitiveness factors that has been analyzed from the early years till nowadays, definitions differ only because of the different aspects that leads to bigger export markets. However, Krugman (1996) pointed out, that "changes in exports and imports have little effect on overall employment", and thus it is not so important factor to increase competitiveness of a country.

Porter $(1990 ; 1998)$ has pioneered the use of economic analysis to investigate important issues relating to 'competitiveness' at the firm, industry and national level. $\mathrm{He}$ is one of the world's leading authorities on the competitive strategy of enterprises, the competitiveness and economic development of nations, states, and regions (Snowdon \& Stonehouse, 2006).

Porter (1990) also was one of the first authors who started to analyze the role of clusters in increasing national competitiveness; he analyzed how a group of close-by, supporting industries creates competitive advantage in a range of interconnected industries that are all internationally competitive. Later many other researchers included competitive clusters as one of the main competitiveness factors in their research. The summary about competitiveness from the analyzed scientific works is given in the Table 1.

Table 1

Competitiveness Sources and Results - Short Summary

\begin{tabular}{|c|c|c|}
\hline Source of competitiveness & Authors & $\begin{array}{c}\text { Result of } \\
\text { competition }\end{array}$ \\
\hline $\begin{array}{l}\text { Factors of productions, absolute } \\
\text { advantage }\end{array}$ & Smith (1776) cited by Garelli (2006) & \multirow{13}{*}{$\begin{array}{l}\text { Welfare } \\
\text { Quality of } \\
\text { life } \\
\text { Sustainability } \\
\text { Development } \\
\text { Growth }\end{array}$} \\
\hline Comparative advantage & Ricardo (1817) cited by Garelli (2006) & \\
\hline $\begin{array}{l}\text { Socio-economic and political } \\
\text { environment }\end{array}$ & Marx (1867) cited by Garelli (2006) & \\
\hline Values, religion, culture & $\begin{array}{l}\text { Weber (1905) cited by Garelli (2006); Herciu, Ogrean, \& Belascu (2011); } \\
\text { Alberti \& Giusti (2012) }\end{array}$ & \\
\hline $\begin{array}{l}\text { Entrepreneurship, innovations, } \\
\text { effectiveness, profitability, } \\
\text { development of technology }\end{array}$ & $\begin{array}{l}\text { Schumpeter (1942) cited by Adler (2019); Solow (1957) cited by Garelli (2006); } \\
\text { Racko (2013); Unterlass et al. (2015); Zykiene, Snieska, Bruneckiene, \& } \\
\text { Burksaitiene (2020) }\end{array}$ & \\
\hline $\begin{array}{l}\text { Knowledge, skills, education, } \\
\text { ethno-competitiveness, } \\
\text { intellectual capital }\end{array}$ & $\begin{array}{l}\text { Pinch, Henry, Jenkins, \& Tallman (2003); Heijman, Van Ophem, \& Bronisz } \\
\text { (2012); Morin \& Ramon (2017); Januskaite \& Uziene (2018) }\end{array}$ & \\
\hline Environment, ecology & $\begin{array}{l}\text { Kourilova, Wokoun, Damborsky, \& Krejcova (2012); Aiginger, Bärenthaler- } \\
\text { Sieber \& Vogel (2013); Aiginger \& Firgo (2015) }\end{array}$ & \\
\hline Productivity & Porter (1990); Krugman (1996); Delgado, Ketels, \& Porter (2012) & \\
\hline $\begin{array}{l}\text { Attractiveness and marketing of } \\
\text { territory }\end{array}$ & $\begin{array}{l}\text { Kitson, Martin, \& Tyler (2004); Malecki (2004, 2007); Ignatjevs (2010); } \\
\text { Huggins, Izushi, \& Thompson (2013); Racko (2013); Shapoval (2018); Annoni, } \\
\text { De Dominicis, \& Khabirpour (2019) }\end{array}$ & \\
\hline Clusters & $\begin{array}{l}\text { Porter (1998); Boronenko (2009); Gilbert, McDougall, \& Audretsch (2013); } \\
\text { Racko (2013); Krzelj-Colavic (2015); Ketels (2015); Zeibote (2018) }\end{array}$ & \\
\hline $\begin{array}{l}\text { Good governance, effective } \\
\text { legislation }\end{array}$ & $\begin{array}{l}\text { Pike, Rodriguez-Pose, \& Tomaney (2006); Pekarsiene, Bruneckiene, Daugeliene, } \\
\text { \& Peleckiene (2018) }\end{array}$ & \\
\hline $\begin{array}{l}\text { Globalisation, integration, trade } \\
\text { openness, export capacity }\end{array}$ & $\begin{array}{l}\text { Pike, Rodriguez-Pose, \& Tomaney (2006); Camagni, \& Capello (2013); De la } \\
\text { Vega, Azorin, Segura, \& Yago (2019) }\end{array}$ & \\
\hline Happiness & Cheung \& Chan (2011); Muchdie (2017) & \\
\hline
\end{tabular}




\begin{tabular}{|l|l|c|}
\hline \multicolumn{1}{|c|}{ Source of competitiveness } & \multicolumn{1}{c|}{ Authors } & $\begin{array}{c}\text { Result of } \\
\text { competition }\end{array}$ \\
\hline Smart specialization & $\begin{array}{l}\text { Thissen, Van Oort, Diodato, \& Ruijs (2013); Unterlass } \text { et al. (2015); Aleksejeva } \\
\text { et al. (2018); Dagiliene, Bruneckiene, Jucevicius, \& Lukauskas (2020) }\end{array}$ & \\
\hline Health care & Bris (2014); Lee (2016); Goswami (2019) & \\
\hline
\end{tabular}

From the Table 1 it is also possible to conclude that one more source of competitiveness is cultural dimension. And here is the space for the discussion - what is culture and how we can understand this term? Culture is a wide concept, the example for this is the definition of culture as civilization: "Culture or civilization, taken in its wide ethnographic sense, is that complex whole which includes knowledge, belief, art, morals, law, custom, and any other capabilities and habits acquired by man as a member of society" (Tylor, 1920). But this term could be understood in the narrower aspect as well: "Culture is the characteristics and knowledge of a particular group of people, encompassing language, religion, cuisine, social habits, music and arts" (Zimmermann, 2017). The wide understanding of culture leads to different studies about culture as a factor of competitiveness. Six dimensions of national culture were defined by Dutch social psychologist Geert Hofstede and his colleagues. They were: Power Distance, Uncertainty Avoidance, Individualism, Masculinity, Long Term versus Short Term Orientation, and Indulgence versus Restraint (Hofstede, 2011). Later those factors were observed as factors of national or regional competitiveness. For example, the study of Herciu, Ogrean, and Belascu (2011) demonstrated, that there is a strong correlation between cultural dimensions and national competitiveness. But Alberti and Giusti (2012) studied only one aspect of culture - cultural heritage and tourism and how they affect regional competitiveness.

Health and health care are studied as the source of competitiveness mostly by researchers from health care, medicine and biology field, for example Goswami (2019), who pointed out that health has been considered as one of the remarkable elements that results in the increase in GDP thus leading to the higher level of the competitiveness in the country. But there are also researchers from the economic and finance field who are studying health as the factor of competitiveness. Bris (2014) concludes that differences in health policies are creating a significant gap in competitiveness between rich and poor economies. Such aspects of competitiveness definitions as territory marketing, globalization and integration, smart specialization and happiness appeared in the 21st century.

Systematic content analysis of existing competitiveness definitions was done by some authors, for example Lee and Karpova (2018), Siudek and Zawojska (2014), Voinescua and Moisoiua (2015). The main conclusion from their research is that words used to characterize competitiveness or results of competitiveness are: productivity, standard of living, growth, well-being, welfare, sustainability. They are almost the same that were discovered by the authors of the article. This means that these goals will be achieved if the competitiveness of the regions will be promoted.

However, despite the contribution of various authors, there is still no common, generally accepted definition of regional competitiveness and its evaluation methodologies. But the authors of the article conclude, that one definition and competitiveness model with the same indicators for regional competitiveness in the whole world is almost impossible, because scientists are representing different areas of research and they will use the factors and indicators to characterize competitiveness according to their research interests or specific situation within the country or region. Based on the analyzed research and emphasizing the main task of the region's competitiveness - to increase the living standards of its inhabitants, the authors of the article provide the following improved definition of the region's competitiveness: The regional competitiveness is the ability to meet the needs of the region's population and to ensure the highest possible standard of living most efficiently using the existing and attracting the necessary resources. This definition will be the basis to develop model of regional competitiveness. To develop such model, it is necessary to find out most important factors characterizing competitiveness.

Porter (1990) notes that factors affecting regional competitiveness are both macroeconomic and local. He has developed the Diamond model or model of determinants of national competitive advantage. The basic factors of this model (factor and demand conditions, related and supporting industries, firm strategy, structure and rivalry) could be affected by two other factors - opportunity or force majeure situations and government work. Some scientists have developed Pyramid or Iceberg models to show factors affecting regional competitiveness (Gardiner et al. (2004), Ketels (2015), Lengyel \& Kano (2012), Blandinieres et al. (2017)). The main idea of Pyramid models is to show the sources of competitiveness at the base of pyramid, and the results of competitiveness will be at the top the pyramid. There are also Onion models of competitiveness factors famous in the scientific literature. They are most often used to show factors of different levels of competitiveness - micro, mezzo, macro (Ritchie \& Crouch (2003), Zmuda (2018)). A group of scientists from the international economic research and consulting firm ECORYS offer a Competitiveness Tree model which shows how the complex factors of competitiveness lead to positive outcomes: social inclusion, prosperity and sustainability. It is not just another general concept of competitiveness, but a specific model aimed at demonstrating the role of regional policy (Bulu, 2012). The Competitiveness Tree model emphasizes the cyclical nature of competitiveness, so it is important to identify the various existing interdependencies in order to understand the ongoing processes.

Various methods are used to evaluate regional competitiveness, but the most popular method is to calculate synthetic index of regional competitiveness. Most of the regional competitiveness indexes are developed to evaluate competitiveness of regions in one specific country, for example, regional competitiveness of the UK regions is evaluated by Birnie, Johnston, Heery, and Ramsey (2019); comparison between Belgian and German 
regions was done by Konings and Marcolin (2011); Aquilino and Wise (2016) did the evaluation of the competitiveness of the Northern and Southern macroregions of Italy. In recent years, regional competitiveness indexes were developed also in the new EU member states, for example in Latvia (Vesperis (2012), Judrupa and Senfelde, 2018), in Lithuania (Snieska and Bruneckiene, 2009), in Poland (Bronisz, Heijman, \& Miszczuk, 2008), in Bulgaria (Ivanov, 2018), and in Romania (Costa, 2017). Only several indexes are used internationally. The most popular international indexes that could be used to evaluate regional or national competitiveness are:

- The Global Competitiveness Index (World Economic Forum, 2019);

- Index of Economic Freedom (The Heritage Foundation, 2020);

- Ease of Doing Business rankings (The World Bank, 2020);

- World Competitiveness ranking (IMD World Competitiveness Centre, 2020);

- The EU Regional Competitiveness Index (European Commission, 2019);

- The Global Sustainable Competitiveness Index (SolAbility, 2019)

All of those indexes are developed based on different aspects of competitiveness, for example, human capital, infrastructure, ICT development, good governance, health, natural capital, social capital etc. The above mentioned international indexes are not applicable at the regional level, because most of them are developed for evaluation of national competitiveness and there is a lack of official statistics on many indicators at regional level. Even the EU Regional Competitiveness Index is calculated at the NUTS 2 level and it's not possible to use all those indicators at NUTS 3 level. The other problem is the use of survey data while to calculate the Regional Competitiveness Index (RCI) for Latvia the limitation is to use only official statistical data.

This is also clear that competitiveness can only be determined in comparison with other similar objects. Competitiveness assessment criteria can be defined in different aspects depending on the task and goal to be solved. Therefore, one of the most important tasks is the selection of indicators characterizing the competitiveness of the region. An optimal system of indicators would allow to understand the regularities that determine and influence the competitiveness of the regions, to forecast the further development trends and the necessary resources to improve competitiveness.

\section{Data and Methodology}

Based on the literature review and analysis of the factors used to calculate international indexes the authors of the article developed the Onion model of regional competitiveness factors (see Figure1.)

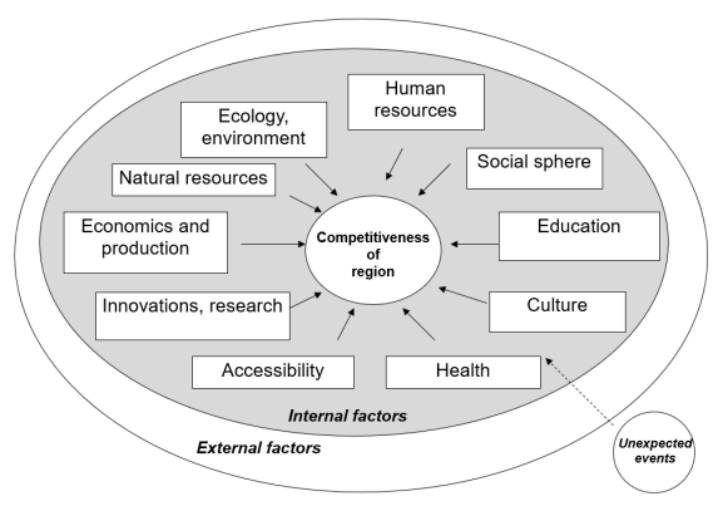

Figure 1. The Onion Model of the Regional Competitiveness (Judrupa, \& Senfelde, 2018)

Regional competitiveness depends on the internal factors (inside the region) and it is the interaction of human resources, social sphere, culture, infrastructure and other factors. Likewise, the external factors, that could be political stability, well developed strategies of country, its participation in different international organizations, unions etc., have significant role in the evaluation of the regional competitiveness. The regional competitiveness can also be significantly influenced by force majeure events - natural disasters (floods, storms, earthquakes, pandemics, etc.). Due to the limitations (time and scope of the study) the externals factors of the regional competitiveness will not be analyzed in the research.

A limited number of indicators were selected to characterize each factor. According to limitations of the study only the official statistical data were used without taking into account the qualitative indicators. Previous study of index calculation methods showed that very often relative weights of indicators were applied to calculate indexes. Weighting allows to increase or decrease the importance of indicators or factors.

If there are few factors, then no special method is needed to assess the importance of the factors. In case of many factors the special method would help to get better evaluation results. The Scoring method was used to assess importance of regional competitiveness factors in this research. It is the experts' method and according to this method, the expert first assigns a score to each factor and then the importance is calculated. The researcher is preparing special table in Excel file, where all necessary formulas are already inserted, and the task of experts is only to fill the column with scores. Advantages of the method: it is precise and fast, because it is faster to give points than try to evaluate importance in decimals or on a 100-point scale. This method is comparatively simple and it is easy to explain it to the experts. The Scoring method is shown in the Table 2.

Table 2

Scoring Method to Calculate Relative weights of Factors

\begin{tabular}{|c|c|c|}
\hline Factors & Scores & Relative weights \\
\hline$F_{1}$ & $S_{1}$ & $\alpha_{1}=S_{1} / S_{T}$ \\
\hline$F_{2}$ & $S_{2}$ & $\alpha_{2}=S_{2} / S_{T}$ \\
\hline$F_{3}$ & $S_{3}$ & $\alpha_{3}=S_{3} / S_{T}$ \\
\hline$\ldots$ & $\ldots$ & $\ldots$ \\
\hline$F_{n}$ & $S_{n}$ & $\alpha_{n}=S_{n} / S_{T}$ \\
\hline
\end{tabular}




\begin{tabular}{|c|c|c|}
\hline Factors & Scores & Relative weights \\
\hline & $S_{T}=\sum_{i=1}^{n} S_{i}$ & $\sum_{i=1}^{n} \alpha_{i}=1$ \\
\hline
\end{tabular}

To weight the factors, authors of the article asked 6 regional development experts in Latvia to evaluate importance of 10 competitiveness factors according to the Scoring method. The results are summarized in the Table 3.
From the Table 3 we can see that the most significant factors of the regional competitiveness with the highest weight 0.16 according to the experts are accessibility and the level of economy and production. The second important aspect is education with the relative weight 0.13 . The lowest relative weight $(0.02)$ is for the development of the cultural sector, and relatively small (0.06) for the existence of natural resources in the region.

Table 3

Relative weights of Competitiveness Factors - Results Obtained from Experts

\begin{tabular}{|c|c|c|c|c|c|c|c|c|}
\hline Factors & Expert 1 & Expert 2 & Expert 3 & Expert 4 & Expert 5 & Expert 6 & Average score & $\begin{array}{c}\text { Relative } \\
\text { weight }\end{array}$ \\
\hline Fc - Human resources & 6 & 6 & 7 & 5 & 5 & 6 & 5.83 & 0.10 \\
\hline Fs - Social sphere & 4 & 5 & 4 & 7 & 3 & 8 & 5.17 & 0.09 \\
\hline FIz - Education & 9 & 7 & 8 & 6 & 8 & 7 & 7.50 & 0.13 \\
\hline FK - Culture & 5 & 9 & 5 & 4 & 4 & 5 & 5.33 & 0.09 \\
\hline Fv - Health care & 1 & 2 & 1 & 2 & 2 & 3 & 1.83 & 0.03 \\
\hline FP - Accessibility & 8 & 8 & 10 & 10 & 9 & 10 & 9.17 & 0.16 \\
\hline FIN - Innovations and research & 7 & 6 & 6 & 5 & 6 & 9 & 6.50 & 0.11 \\
\hline $\mathrm{F}_{\mathrm{R}}$ - Economy and production & 10 & 10 & 9 & 9 & 10 & 7 & 9.17 & 0.16 \\
\hline FD - Natural resources & 2 & 3 & 2 & 3 & 7 & 4 & 3.50 & 0.06 \\
\hline FE - Ecology and environment & 3 & 4 & 3 & 8 & 4 & 5 & 4.50 & 0.08 \\
\hline & & & & & & Total & 58.5 & 1 \\
\hline
\end{tabular}

To calculate RCI and its 10 factors $\left(F_{n}\right) 39$ indicators $\left(f_{n}\right)$ were selected. They are summarized in the Table 4. The total data set for analysis was 4680 values (780 values per region).
The choice of the number of indicators depended on the availability of statistics and the aspect of competitiveness characterized by indicators as it was important that the indicators did not overlap.

Indicator System for the Regional Competitiveness Evaluation in Latvia and Relative weights of Sub-Indexes (Judrupa, \& Senfelde, 2018)

\begin{tabular}{|c|c|c|c|}
\hline Factors & Indicators & Factors & Indicators \\
\hline $\begin{array}{l}\text { Human } \\
\text { resources } \\
F_{C}=0,10\end{array}$ & $\begin{array}{l}\text { 1. Number of inhabitants, people } \\
\text { 2. Proportion of population under working } \\
\text { age, } \% \\
\text { 3. Proportion of population in working } \\
\text { age, } \%\end{array}$ & $\begin{array}{l}\text { Accessibilit } \\
F_{P}=0,16\end{array}$ & $\begin{array}{l}\text { 17. Distance from district centres to Riga, } \mathrm{km} \\
\text { 18. National and municipal road density, } \mathrm{km} \text { per } \\
1000 \mathrm{~km}^{2} \\
\text { 19. Cargos in ports, } t \\
\text { 20. Number of passengers arriving and leaving } \\
\text { with passenger ships and ferries, people } \\
\text { 21. Number of passengers arriving and leaving } \\
\text { from airports, people } \\
\text { 22. Availability of computers in households, } \% \\
\text { 23. Availability of Internet in households, } \%\end{array}$ \\
\hline $\begin{array}{l}\text { Social } \\
\text { sphere } \\
F_{S}=0,09\end{array}$ & $\begin{array}{l}\text { 4. Unemployment rate, } \% \\
\text { 5. Average monthly net wage of workers, } \\
\text { EUR } \\
\text { 6. Housing stock per inhabitant, } m^{2} \\
\text { 7. Proportion of guaranteed minimum } \\
\text { income benefit recipients in total } \\
\text { regional population, } \%\end{array}$ & $\begin{array}{l}\text { Innovation } \\
\text { and } \\
\text { research } \\
F_{I N}=0,11\end{array}$ & $\begin{array}{l}\text { 24. Proportion of enterprises performing research } \\
\text { among active enterprises in the region, } \% \\
\text { 25. Proportion of employees in enterprises } \\
\text { performing research of the total number of } \\
\text { workers in the region, } \% \\
\text { 26. Total expenditure for research, EUR }\end{array}$ \\
\hline $\begin{array}{l}\text { Education } \\
F_{I Z}=\mathbf{0 , 1 3}\end{array}$ & $\begin{array}{l}\text { 8. Proportion of population with vocational } \\
\text { education, secondary vocational } \\
\text { education and general secondary } \\
\text { education of the total regional population } \\
\text { (15-74 years), \% } \\
\text { 9. Proportion of population with higher } \\
\text { education of the total regional population } \\
\text { (15-74 years), } \%\end{array}$ & $\begin{array}{l}\text { Economy } \\
\text { and } \\
\text { production } \\
F_{R}=0,16\end{array}$ & $\begin{array}{l}\text { 27. GDP per employee, EUR } \\
\text { 28. Economically active enterprises per } 1000 \\
\text { inhabitants, enterprises } \\
\text { 29. Added value of agriculture sector per } \\
\text { inhabitant, EUR per inhabitant } \\
\text { 30. Added value of industrial sector per inhabitant, } \\
\text { EUR per inhabitant } \\
\text { 31. Added value of service sector per inhabitant, } \\
\text { EUR per inhabitant }\end{array}$ \\
\hline $\begin{array}{l}\text { Culture } \\
F_{K}=0,03\end{array}$ & $\begin{array}{l}\text { 10. Public library readership, people } \\
\text { 11. Number of museums, museums } \\
\text { 12. Proportion of traditional culture and } \\
\text { amateur art participants of the total } \\
\text { regional population, } \%\end{array}$ & $\begin{array}{l}\text { Natural } \\
\text { resources } \\
F_{D}=0,06\end{array}$ & $\begin{array}{l}\text { 32. Territory, thousand } \mathrm{km}^{2} \\
\text { 33. Sea border, } \mathrm{km} \\
\text { 34. Total stocks of construction materials, } \% \\
\text { 35. Forest cover, } \%\end{array}$ \\
\hline Health care & $\begin{array}{l}\text { 13. Number of doctors per } 1000 \text { inhabitants, } \\
\text { people }\end{array}$ & $\begin{array}{l}\text { Ecology, } \\
\text { environme }\end{array}$ & $\begin{array}{l}\text { 36. Household waste per } 1 \mathrm{~km}^{2}, t \\
\text { 37. Hazardous waste per } 1 \mathrm{~km}^{2}, t\end{array}$ \\
\hline
\end{tabular}




\begin{tabular}{|l|l|l|l|}
\hline$F_{V}=0,09$ & $\begin{array}{l}\text { 14. } \begin{array}{l}\text { Medical personnel with secondary } \\
\text { medical education per } 1000 \text { inhabitants, } \\
\text { people }\end{array} \\
\text { 15. } \begin{array}{l}\text { Number of hospital beds, beds } \\
\text { Number of deaths per } 1000 \text { inhabitants, } \\
\text { people }\end{array}\end{array}$ & $\begin{array}{l}\text { 38. Harmful emissions into the atmosphere, } t \\
\text { 16. Polluted wastewater proportion of the total } \\
\text { wastewater, \% }\end{array}$ \\
\hline
\end{tabular}

The next step in the development of the RCI is normalization of indicators. Normalized indicators are calculated from the original indicators, which are marked in $\%$, pieces, $\mathrm{km}$ etc. In the process of normalization, the original units of measurement disappear and it becomes possible to compare different indicators. Two different approaches are used to normalize indicators, because one of the tasks of the study is to compare whether there are differences in the levels of competitiveness of regions when the index is calculated according to different methods.

As the $1^{\text {st }}$ method for normalization of indicators the minmax normalization was used (Formula 1).

$$
X_{\text {norm }}=2 \frac{x-x_{\min }}{x_{\max }-x_{\min }}-1
$$

where:

$\mathrm{X}_{\text {norm }}$ - normalized indicator;

$\mathrm{x}$ - actual value of the indicator;

$\mathrm{x}_{\min }-$ minimum value of the indicator among the regions;

$\mathrm{x}_{\max }-$ maximum value of the indicator among the regions.

The $2^{\text {nd }}$ method to normalize indicators is to calculate $\%$ from the average value and it is expressed by Formula 2 .

$$
X_{n o r m}=\frac{x}{x_{a v r}} \cdot 100 \%
$$

where:

$\mathrm{X}_{\text {norm }}$ - normalized indicator;

$\mathrm{x}$ - actual value of the indicator;

$\mathrm{X}_{\mathrm{avr}}-$ average value of the indicator in the regions.

By using Formula 1 the values of the RCI will be in the interval $[-1 ; 1]$, where -1 is the worst indicator and 1 is the best indicator. By using Formula 2 the average value of the RCI for all regions will be $100 \%$ and there are no limits for maximum and minimum values of the RCI. The RCI includes 10 sub-indexes and their relative weights. In general, RCI is the function of the selected factors that tends towards maximum, and can be calculated as a weighted mean by using Formula 3.

$$
R C I=\sum_{i=1}^{n}\left(\alpha_{i} F_{i}\right) \rightarrow 1, \text { where } \sum_{i=1}^{n} \alpha_{i}=1
$$

where:

RCI - Regional Competitiveness Index;

$\alpha_{i}$ - relative weights of the factors;

$\mathrm{F}_{\mathrm{i}}$ - sub-indexes of the RCI.

Sub-index of each factor group is calculated as an arithmetic mean by taking into account all indicators of the group, applying one of the above mentioned normalisation formulas (Formula 1 or Formula 2):

$$
F_{n}=\frac{1}{n} \sum_{i=1}^{n}\left(2 \cdot \frac{f_{i}-f_{\min _{i}}}{f_{\max _{i}}-f_{\min _{i}}}-1\right)
$$

$$
F_{n}=\frac{1}{n}\left(\sum_{i=1}^{n} \frac{f_{i}}{f_{a v r_{i}}}\right) \cdot 100 \%
$$

where:

$F_{n}$ - sub-index of the RCI;

$f_{i}$ - actual values of the indicators;

$f_{\min } i ; f_{\max } i-$ minimum and maximum values of the indicators;

$f_{\text {avr } i}$ - average value of the indicators;

$\mathrm{n}$ - number of the indicators.

RCI calculation was based on the secondary data from Central Statistical Bureau of Latvia, Latvian Centre for Environment, Geology and Meteorology, and State Forest Service. At the beginning sub-indexes $F_{n}$ of each factor group are calculated. After the calculation of the subindexes, it is possible to calculate the total competitiveness index RCI.

\section{Results and Discussion}

The results of calculations for each statistical region of Latvia according to both methods (by using Formula 4 and Formula 5) are illustrated in the Figure 2.

Data in the Figure 2 shows that according to both methods the most competitive is Riga region and its competitiveness level is considerably higher than competitiveness of other statistical regions of Latvia. Latgale region is at the last place.

According to the $1^{\text {st }}$ method RCI of Riga statistical region was 0.3601 in 2019 (the maximum possible value is 1). It means that even the Riga region doesn't reach maximum competitiveness level and it is not close to maximum, but it is the only region which competitiveness level is above the average (0). If to compare this method with the $2^{\text {nd }}$ method of index calculation, it shows greater difference among performance of regions. And it is possible to see, that competitiveness of Pieriga region has increased by time. The advantage of min-max normalization is that the boundaries of the range, in which the index values will be, can be changed depending on the needs of the researcher. This index is easy to understand and explain. It allows to compare regions in the period of time and among each other.

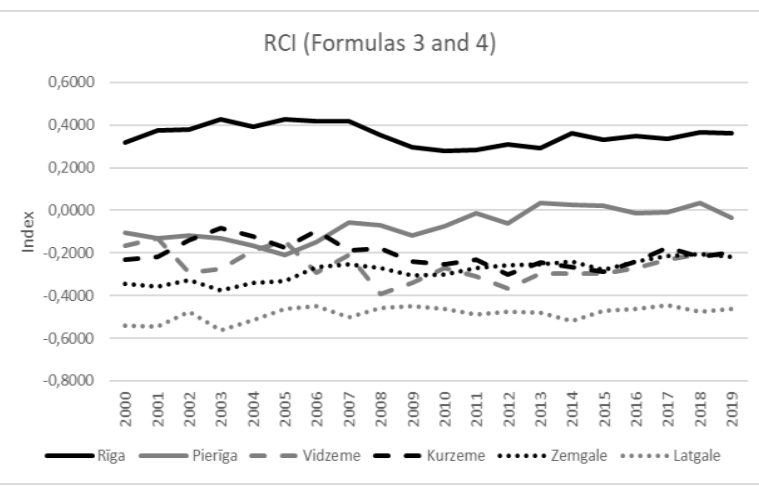




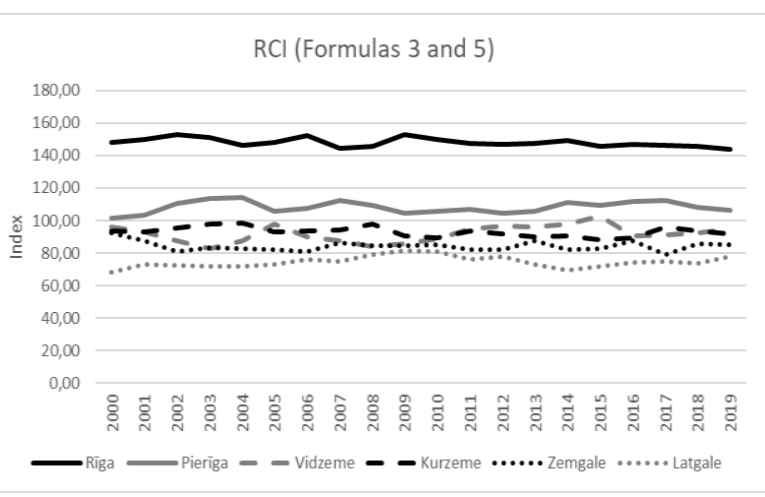

Figure 2. Results of the RCI Calculation in the Statistic Regions of Latvia According to two Different Methods

According to the $2^{\text {nd }}$ method competitiveness of Riga statistical region was $144.04 \%$ in 2019. It means that it is 44.04 percentage points higher than the average level of Latvia. Only in Riga and Pieriga regions competitiveness level is above the average (100\%). Competitiveness level of other regions of Latvia is below the average and Latgale region takes the last place. The regions are placed closer to each other and difference between best and worst region is not so big in comparison to the previous method. The disadvantage of this method is that it is not possible to assess how competitiveness has changed over time, because the average level is $100 \%$ throughout the analyzed period, regardless of whether it has increased or decreased. This index is also easy to understand and explain. The authors of the article chose to calculate RCI taking into account relative weights of the factors. But the question arises - is there a difference between results of calculations if relative weights will not be used? In this case the final RCI is calculated as arithmetical mean of all sub-indexes by using Formula 6 .

$$
R C I=\frac{1}{n} \sum_{i=1}^{n} F_{i} \rightarrow \max
$$

where:

RCI - Regional Competitiveness Index;

$\mathrm{F}_{\mathrm{i}}$ - sub-indexes of the RCI;

$\mathrm{n}$ - number of factors.

Riga region and Method 1 (min-max normalization) for index calculation was chosen to illustrate results (for other regions the results were similar).

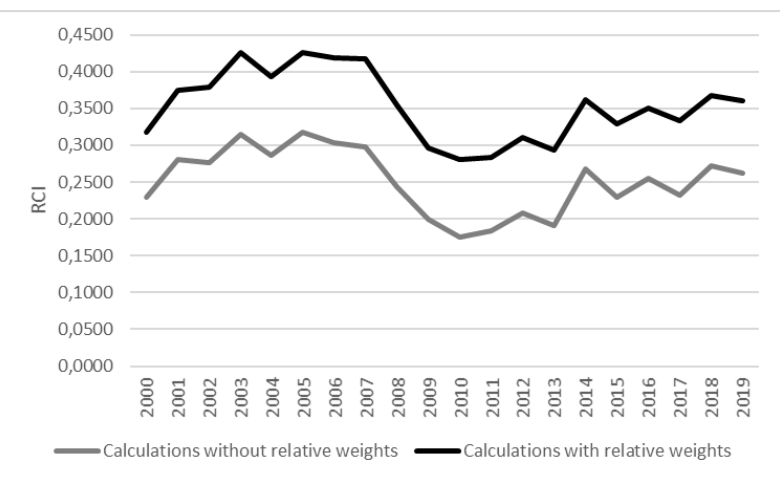

Figure 3. RCI for Riga Region According to the Method 1 with and Without Relative Weights

It is possible to conclude that in the situation when relative weights were used the competitiveness level of Riga region was higher, because those factors that had the highest scores were also the most important ones. The use of relative weights can affect the results of the index, so their use must be economically justified.

To assess whether simple indicators such as GDP, GDP per capita or GDP per employee could be used to evaluate competitiveness of regions the analysis of before mentioned indicators was done, ranking method was applied and correlation coefficient was calculated to compare those indicators and RCI. For ranking of regions year 2017 was chosen because this was the latest period for which official statistics were available. For calculation of correlation coefficient research period was 2000-2017. The results are summarized in the Table 5.

Table 5

\section{Rankings and Correlation Coefficients of Statistical Regions of Latvia}

\begin{tabular}{|c|c|c|c|c|}
\hline \multirow[t]{2}{*}{ Region } & \multicolumn{4}{|c|}{ Rank 2017} \\
\hline & RCI & GDP & GDP/capita & GDP/employee \\
\hline Riga & 1 & 1 & 1 & 1 \\
\hline Pieriga & 2 & 2 & 2 & 2 \\
\hline Vidzeme & 5 & 6 & 4 & 4 \\
\hline Kurzeme & 3 & 3 & 3 & 3 \\
\hline Zemgale & 4 & 4 & 5 & 5 \\
\hline Latgale & 6 & 5 & 6 & 6 \\
\hline \multirow[t]{2}{*}{ Region } & \multicolumn{4}{|c|}{ Correlation coefficient - RCI and: } \\
\hline & & & GDP/capita & GDP/employee \\
\hline Riga & & 24137 & -0.26993 & -0.37387 \\
\hline Pieriga & & 30291 & 0.80701 & 0.82118 \\
\hline Vidzeme & & 35796 & -0.29717 & -0.37272 \\
\hline Kurzeme & & 38373 & -0.42162 & -0.48921 \\
\hline Zemgale & & 92227 & 0.93258 & 0.90645 \\
\hline Latgale & & 61528 & 0.58423 & 0.57022 \\
\hline
\end{tabular}

Riga region ranks in the 1st place according to all the studied macroeconomic indicators, as well as according to the RCI. Pieriga region is on the 2nd place and Kurzeme takes the 3rd place. The other statistical regions have changed their positions depending on which indicator is being analysed. In turn, a significant correlation between RCI and other analysed indicators is observed only in Pieriga and Zemgale regions. This means that it is not possible to measure competitiveness solely on the basis of GDP or GDP-derived indicators. Competitiveness of regions is affected by a number of different, interrelated factors, which do not always directly affect volume of gross domestic product. GDP does not characterise the competitiveness of regions from various aspects. The development of a sound and effective regional development strategy and regional development policy should be based on the results and analysis of the Regional Competitiveness Index. The detailed analysis of RCI (indicators, sub-indexes) will allow to determine the areas for each region that are more or worse competitive and will allow to allocate financial resources more effectively. It is possible to find factors fostering or hindering competitiveness for each region and develop action programs to support and stimulate those regions and those fields of competitiveness in which region lags below the average.

\section{Conclusions}

There is no one common definition of regional competitiveness at global or European scale, which makes 
it difficult to develop a methodology for assessing regional competitiveness. However, based on the analysis, it is possible to conclude that all definitions of competitiveness focus on the view that the competitiveness of a region depends on how high and sustainable the level of prosperity in the region is.

Universal model with the same factors and indicators to evaluate regional competitiveness at global scale will be very general. All regions in every country have their own specific advantages and disadvantages, different factors with more or less importance to promote competitiveness. But despite this it is possible to develop the methodology using official statistical information (hard data) to evaluate regional competitiveness. The methodology proposed by the authors allows assessing the competitiveness of any region, it is only necessary to adjust the factors' weights and selected indicators for the specific country or region of the world.

Authors of the article calculated RCI according to two different methods. The results obtained were similar, but not the same (some of the regions presented higher or lower places among other regions). Each of index calculation methods has its own advantages and disadvantages and the choice of the appropriate method will depend on the researcher's goals and objectives.

By use of relative weights, it is possible to affect the results of the index, so their use must be economically justified.

The regional competitiveness cannot be characterised by such indicators as GDP or GDP per capita, as there are essential differences between the dynamics of these indicators and obtained results from the calculations of the Regional Competitiveness Index. The regional competitiveness is influenced and defined by a wide range of interrelated factors that do not always reflect exactly in the amounts of the gross domestic product.

RCI shows the level of competitiveness of Latvia's statistical regions, it is possible to compare regions in time and among each other. It allows to form regional development policy and strategy more reasonably.

\section{References}

Adler, D. (2019). Schumpeter's Theory of Creative Destruction. Carnegie Melon University, College of Engineering. Available from internet: https://www.cmu.edu/epp/irle/irle-blog-pages/schumpeters-theory-of-creative-destru ction.html

Aiginger, K., Barenthaler-Sieber, S., \& Vogel, J. (2013). Competitiveness under New Perspectives. WWW for Europe Policy Paper No.44, October 2013. Available from internet: http://www.oecd.org/economy/Competitiveness-underNew-Perspectives.pdf

Aiginger, K., \& Firgo, M. (2015). Regional Competitiveness Under New Perspectives. WWW for Europe Policy Paper No.26, October 2015. Available from internet: https://www.researchgate.net/publication/283320305_Regional_Competitiveness_ Under_New_Perspectives. https://doi.org/10.2139/ssrn.2685585

Alberti, F. G., \& Giusti, J. D. (2012). Cultural heritage, tourism and regional competitiveness: The Motor Valley cluster. City, Culture and Society, 3 (4), 261-273. https://doi.org/10.1016/j.ccs.2012.11.003

Aleksejeva, L., Sipilova, V., Jermolajeva, E., Ostrovska, I., \& Olehnovics, D. (2018). Regional risks and challenges in smart growth in Latgale Region (Latvia). Journal of security and sustainability issues, 7 (4), $727-739$. https://doi.org/10.9770/jssi.2018.7.4(10)

Annoni, P., De Dominicis, L., \& Khabirpour, N. (2019). Location matters: a spatial econometric analysis of regional resilience in the European Union. Growth and Change: A Journal of Urban and Regional Policy, 50 (3), $824-855$. https://doi.org/10.1111/grow.12311

Aquilino, L., \& Wise, N. (2016). Evaluating the Competitiveness of the Northern and Southern Macro-Regions of Italy. AlmaTourism 7 (13), 23-47. https://doi.org/10.6092/issn.2036-5195/5988

Birnie, E., Johnston, R., Heery, L., \& Ramsey E. (2019). A critical review of competitiveness measurement in Northern Ireland. Regional Studies, 53 (10), 1494-1504. https://doi.org/10.1080/00343404.2019.1569757

Blandinieres et al. (2017). Measuring Competitiveness. Background documents for the European Semester. EU. Ref. Ares(2018)1159686-01/03/2018.

Boronenko, V. (2009). Klasteru loma regiona konkuretspejas paaugstinasana / The role of clusters in the developmnet of regional competitiveness. Summary of the thesis for obtaining the doctoral degree. Latvia: Latvia University of Agriculture. Available from internet: https://llufb.llu.lv/dissertation-summary/regional-development/Vera Boronenko_Promocijas_darba_kopsavilkums_2009_LLU_EF.pdf

Bris, A. (2014). How important is healthcare to preserve competitiveness? IMD. Available on internet: https://www.imd.org/research-knowledge/articles/com-march-2014/

Bronisz, U., Heijman, W., \& Miszczuk, A. (2008). Regional competitiveness in Poland: Creating an index. Review of Regional Research, 28 (2), 133-143. https://doi.org/10.1007/s10037-008-0026-y

Camagni, R., \& Capello, R. (2013). Regional Competitiveness and Territorial Capital: A Conceptual Approach and Empirical Evidence from the European Union. Regional Studies, 47 (9), 1383-1402. https://doi.org/10.108 $0 / 00343404.2012 .681640$ 
Central Statistical Bureau of Latvia. (2020). CSB Database. Available on internet: https://www.csb.gov.lv/en/statistika/db

Cheung, H. Y., \& Chan, A. W. H. (2011). The relationship of competitiveness motive on people's happiness through education. International Journal of Intercultural Relations, 35 (2), 179-185. https://doi.org/10.10 16/j.ijintrel.2010.11.008

Costa, C. (2017). The Influence of Regional Development Policies On Regional Competitiveness in Romania. Annals Economy Series, 4, 197-203. Available from internet: https://www.utgjiu.ro/revista/ec/pdf/2017-04/27_Costa.pdf

Dagiliene, L., Bruneckiene, J., Jucevicius, R., \& Lukauskas, M. (2020), Exploring smart economic development and competitiveness in Central and Eastern European countries, Competitiveness Review, 30 (5), $485-505$. https://doi.org/10.1108/CR-04-2019-0041

De la Vega, J. C. S., Azorin, J. D. B., Segura, A. C., \& Yago, M. E. (2019). A new measure of regional competitiveness. Applied Economic Analysis, 27 (80), 108-126. https://doi.org/10.1108/AEA-07-2019-0010

Delgado, M., Ketels, C., \& Porter, M. (2012). The Determinants of National Competitiveness. UK: National Bureau of Economic Research, Cambridge. NBER Working Paper 18249. Available from internet: https://www.researchgate.net/publication/236903847_The_Determinants_of_National_Competitiveness. https://doi.org/10.3386/w18249

European Commission (2019). The EU Regional Competitiveness Index 2019. Available on internet: https://cohesiondata.ec.europa.eu/stories/s/Regional-Competitiveness-Index-2019/363v-4uq6/

Garelli, S. (2006). Competitiveness of Nations: the Fundamentals. IMD World Competitiveness Yearbook 2006. Available from internet: https:/www.yumpu.com/en/document/read/22623403/competitiveness-of-nations-thefundamentals-imd

Gilbert, B.A., McDougall, P.P., \& Audretsch, D.B. (2008). Clusters, knowledge spillovers and new venture performance: An empirical examination. Journal of Business Venturing, 23(4), 405-422. https://doi.org/10.1016/j.jbus vent.2007.04.003

Goswami, K. (2019). Health and National Competitiveness: An Empirical Analysis of the BRICS Nations. Indian Journal of Public Health Research \& Development 10(12), 70-75. https://doi.org/10.37506/v10/i12/2019/ijphrd/192197

Heijman W. J. M., van Ophem, J. A. C., \& Bronisz, U. (2012). Regional Competitiveness, Social and Intellectual Capital. Economic Science for Rural Development, 28, 181-186.

Herciu, M., Ogrean, C., \& Belascu, L. (2011). Culture and national competitiveness. African Journal of Business Management, 5 (8), 3056-3062. https://doi.org/10.5897/AJBM10.145

Hofstede, G. (2011). Dimensionalizing Cultures: The Hofstede Model in Context. Online Readings in Psychology and Culture, 2(1). https://doi.org/10.9707/2307-0919.1014

Huggins, R., Izushi, H., \& Thompson P. (2013). Regional Competitiveness: Theories and Methodologies for Empirical Analysis. The Business and Economics Research Journal, 6 (2), 155-172. https://doi.org/10.7835/jcc-berj-20130086

Ignatjevs, S. (2010). Teritorijas marketings ka regiona strategiskas attistibas factors / Territory marketing as a factor of strategic development of the region. Latvia: Rezeknes Augstskola.

IMD World Competitiveness Centre (2020). World Competitiveness rankings. Available on internet: https://www.imd.org/wcc/world-competitiveness-center/

Ivanov, I. (2018). Study of regional inequalities: case of Bulgaria. Business Management and Education, 16 (1), $27-39$. https://doi.org/10.3846/bme.2018.2275

Januskaite, V., \& Uziene, L. (2018). Intellectual Capital as a Factor of Sustainable Regional Competitiveness. Sustainability, 10(12), 1-18. https://doi.org/10.3390/ su10124848

Judrupa, I., \& Senflede, M. (2018). Latvijas regionu konkuretspejas novertesana / Evaluation of regions' competitiveness in Latvia. Scientific monograph, Latvia: RTU Publishing House, p.150

Ketels, C. (2015). Competitiveness and Clusters: Implications for a New European Growth Strategy. WWW for Europe Working Paper No.84. Available from internet: https://www.hbs.edu/faculty/Publication\%20Files/WWWforEurope WPS_no084_MS48_a00e436c-231c-4cbf-90e1-4e8261219 b6f.pdf

Kitson, M., Martin, R., \& Tyler, P. (2004). Regional Competitiveness: An Elusive yet Key Concept. Regional Studies, 38 (9), 991-999. https://doi.org/10.1080/0034340042000320816

Konings, J., \& Marcolin, L. (2011). The Competitiveness of Regions: A Comparison Between Belgian and German Regions. VIVES Discussion Paper No. 16. https://doi.org/10.2139/ssrn.1888167

Kourilova, J., Wokoun, R., Damborsky, M., \& Krejcova, N. (2012). The competitiveness of EU regions, ERSA conference papers ersa12p788, European Regional Science Association. Available from internet: http://wwwsre.wu.ac.at/ersa/ersaconfs/ersa12/e120821aFinal00790.pdf 
Ilze Judrupa, Maija Senfelde, Vytautas Juscius Evaluation of the Competitiveness of Statistical Regions in Latvia Using ...

Krugman, P. (1996). A Country is not a Company. Harvard Business Review, January-February 1996. Available from internet: https://hbr.org/1996/01/a-country-is-not-a-company

Krzelj-Colovic, Z. (2015). Regional competitiveness. Management and organization. DIEM: Dubrovnik International Economic Meeting, 2 (1), 437-445. Available from internet: https://hrcak.srce.hr/161617

Latvian Center for Environment, Geology and Meteorology. (2020). Statistics on water, air pollution and municipal waste. Available on internet: https://www.meteo.lv/lapas/vide/udens/notekudeni/notekudeni?id=1198\&nid=428

Lee, D. (2016). Comparison of efficiency of healthcare systems of countries with global competitiveness using data envelopment analysis. Global business and finance review, 21 (1), 46-55. https://doi.org/10.17549/gbfr.2016. 21.1.46

Lee, J., \& Karpova, E. (2018). Revisiting the competitiveness theory in the new global environment: review and analysis of the competitiveness definition. International Journal of Competitiveness, 1 (3), 189-205. https://doi.org/10.1504/ IJC.2018.10012626

Lengyel, I., \& Kano, I. (2012). Competitiveness of Hungarian Urban Micro-regions: Localization Agglomeration Economies and Regional Competitiveness Function. Regional Statistics 2(1), 27-44. https://doi.org/10.15196/RS0 2103

Malecki, E. (2004). Jockeying for Position: What It Means and Why It Matters to Regional Development Policy When Places Compete. Regional Studies, 38 (9), 1101-1120. https://doi.org/10.1080/0034340042000292665

Malecki, E. (2007). Cities and Regions Competing in the Global Economy: Knowledge and Local Development Policies. Environment and Planning C: Politics and Space, 25 (5), 638-654. https://doi.org/10.1068/c0645

Morin, L., \& Ramon, D. (2017). Ethnocompetitiveness, relations, and networks: towards rural sustainability. Development in Practice, 27 (7), 1020-1032. https://doi.org/10.1080/09614524.2017.1353589

Muchdie, M. (2017). Human development, global competitiveness and happiness: a cross-national path analysis. International Journal of Advanced Research, 5(10), 779-790. https://doi.org/10.21474/IJAR01/5587

Pekarsiene, I., Bruneckiene, J., Daugeliene, R., \& Peleckiene, L. (2018). The impact of competition policy on the national economy of a country with a developing culture of competition. Inzinerine Ekonomika-Engineering Economics 29(1), 72-83. https://doi.org/10.5755/j01.ee.29.1.18905

Pike, A., Rodriguez-Pose, A., \& Tomaney, J. (2006). Local and Regional Development. UK: Routledge. https://doi.org/10.4324/9780203003060

Pinch, S., Henry, N., Jenkins, M., \& Tallman S. (2003). From 'industrial districts' to 'knowledge clusters': A model of knowledge dissemination and competitive advantage in industrial agglomerations. Journal of Economic Geography 3(4), 373-388. https://doi.org/10.1093/jeg/lbg019

Porter, M. E. (1990). The competitive advantage of nations. Harvard Business Review, 68 (2), 73-93. Available from internet: https://hbr.org/1990/03/the-competitive-advantage-of-nations. https://doi.org/10. 1007/978-1-349-11336-1

Porter, M. E. (1998). The Adam Smith address: Location, clusters and the "new" microeconomics of competition. Business Economics, 33 (1), 7-13. Available from internet: https://www.jstor.org/stable/23487685?seq=1

Racko, E. (2013). Latvijas regionu konkuretspejas novertesana un paaugstinasanas potencials Eiropas Savieniba / Evaluation of the competitiveness of Latvian regions and potential of its increase in the European Union. Summary of the thesis for obtaining the doctoral degree. Latvia: Daugavpils University, p.124. Available from internet: http://du.lv/wp-content/uploads/2015/12/kopsavilkums_racko_save-1.pdf

Ritchie, J. R. B., \& Crouch, G. I. (2003). The Competitive Destination: A Sustainable Tourism Perspective. UK: CABI Publishing. https://doi.org/10.1079/9780851996646.0000

Shapoval, Y. (2018). The marketing role in improving the competitiveness of the region. Baltic Journal of Economic Studies, 3(4), 289-293. https://doi.org/10.30525/2256-0742/2017-3-4-289-293

Siudek, T., \& Zawojska, A. (2014). Competitiveness in the economic concepts, theories and empirical research. Oeconomia, 13(1), 91-108. Available from internet: http://yadda.icm.edu.pl/yadda/element/bwmeta1.element.agrob3b94eea-5c1c-4805-9a76-c82799727548

Snieska, V., \& Bruneckiene, J. (2009). Measurement of Lithuanian Regions by Regional Competitiveness Index. Inzinerine Ekonomika-Engineering Economics, 61 (1), 45-57. https://doi.org/10.5755/j01.ee.61.1.11584

Snowdon, B., \& Stonehouse, G. (2006). Competitiveness in a Globalised World: Michael Porter on the Microeconomic Foundations of the Competitiveness of Nations, Regions, and Firms. Journal of International Business Studies 37(2), 163-175. https://doi.org/10.1057/palgrave.jibs.8400190

SolAbility (2020). The Global Sustainable Competitiveness Index. Available on internet: http://solability.com/the-globalsustainable-competitiveness-index/the-index

State Forest Service (2020). Statistics on forests. Available on internet: https://www.vmd.gov.lv/valsts-mezadienests/statiskas-lapas/publikacijas-un-statistika/meza-statistikas-cd?nid=1809\#jump

The Heritage Foundation (2020). Index of Economic Freedom. Available on internet: https://www.heritage.org/index/ 
The World Bank (2020). Ease of Doing Business rankings. Available on internet: https://www.doingbusiness.org /en/rankings

Thissen, M., Van Oort, F., Diodato, D., \& Ruijs, A. (2013). Regional Competitiveness and Smart Specialization in Europe, UK: Edward Elgar. https://doi.org/10.4337/9781782545163

Tylor, E. B. (1920). Primitive culture: researches into the development of mythology, philosophy, religion, language, art, and custom. Vol.I. UK, London: John Murray. Avalaibale from internet: https://archive.org/details/ primitiveculture01tylouoft/page/n519/mode/2up

Unterlass, F. et al. (2015). The relationship between export and technological specialisation profiles across EU Member States and regions and the identification of development potentials. WIFO Studies, WIFO, number 58911, December 2015. Austria: Osterreichisches Institut fur Wirtschaftsforschung.

Vesperis, V. (2012). Regionalas attistibas novertesana / Regional development assessment. Summary of the thesis for obtaining the doctoral degree. Latvia: Latvia University of Agriculture. Available from internet: https://llufb.llu.lv/dissertationsummary/regional-development/V_Vesperis_promoc_darba_kopsavilkums_2012_LLU_EF.pdf

Voinescua, R., \& Moisoiua, C. (2015). Competitiveness, Theoretical and Policy Approaches. Towards a more competitive EU. Procedia Economics and Finance 22, 512-521. https://doi.org/10.1016/S2212-5671(15)00248-8

World Economic Forum (2019). Global Competitiveness Report 2019. Available on internet: http://www3.weforum.org/ docs/WEF_TheGlobalCompetitivenessReport2019.pdf

Zeibote, Z. (2018). Klasteri ka regionalo politiku un konkuretspeju ietekmejoss faktors / Clusters as a factor influencing regional policy and competitiveness. Summary of the thesis for obtaining the doctoral degree. Latvia: Baltic International Academy. Available from internet: https://bsa.edu.lv/wp-content/docs/science/2020/zanezeibote.pdf

Zimmermann, K. A. (2017). What is culture? Live Science. Available from internet: https://www.livescience.com/21478what-is-culture-definition-of-culture.html

Zmuda, M. (2018). Modelling the competitiveness of a catching-up economy. Germany: Cologne Business School, Working paper 05, p. 36. Available from internet: https://www.researchgate.net/publication/331488821_Modelling _the_competitiveness_of_a_catching-up_economy

Zykiene, I., Snieska, V., Bruneckiene, J., \& Burksaitiene, D. (2020). Assessment of regions using an index for a location's attractiveness for business development. Economic Research, 00, 1-20. https://doi.org/10.1080/1331677X. 2020.1825106

\section{Authors' Biographies}

Ilze Judrupa, Dr.oec, is an Associated Professor at Riga Technical University Faculty of Engineering Economics and Management. She received the Ph.D. degree in economics from RTU in 2011 and has 20 years' experience of pedagogical and scientific work. She has participated in various research projects related to regional development and competitiveness of countries. In 2012-2014 she participated in INTERREG IVC project "MICROPOL: promoting development and innovation through Smart Work Centres in non-metropolitan Europe", where her research interests included development of Smart Work Centres. Her current research interests include regional development and competitiveness.

Maija Šenfelde holds a Doctor degree in Economics (1993) from Scientific Council of Latvian University. She has been working for Riga Technical University in different positions. Since 2003 Maija Šenfelde is Profesor of Faculty of Engineering Economics and Management, from 1997 to 2007 she was a Deputy Dean for Studies, from 2009 to 2014 she was a Director of Institute of National and Regional Economy, since 2014she is Head of Departament of territorial development Management and Urban Economics. Main fields for research are macroeconomics,international and regional economics. She has published scientific papers in peer-reviewed journals and articles and is the author of study books as well. Maija Šenfelde is Expert of Latvian Science Council, Member of Promotion Council, Member of Professors Council of RTU etc.

Vytautas Juščius, PhD in Social Sciences (Economics), professor, head of Economics Department at Klaipeda University Faculty of Social Sciences. He is a member of the Editorial Board at the International Journal "Regional Formation and Development Studies". His research interests include corporate social responsibility, globalization, competitiveness, sustainable development. He is the author of more than 50 national and international publications.

The article has been reviewed.

Received in November 2020; accepted in April 2021.

This article is an Open Access article distributed under the terms and conditions of the Creative Commons Attribution 4.0 (CC BY 4.0) License (http://creativecommons.org/licenses/by/4.0/). 